\title{
Mineralogical and Physicochemical Characterization of Clay in the Sangaré-Paul Locality (North Cameroon), in Order to Assess the Potential Use in the Field of Ceramics
}

\author{
Mominou Nchare ${ }^{1}$, Essimi Onana Bonaventure Desire ${ }^{1}$, Wang Lei ${ }^{2}$, Badohok Sarki ${ }^{1}$ \\ ${ }^{1}$ Department of Mining \& Extractive Metallurgy, School of Geology \& Mining Engineering, University of Ngaoundéré, \\ Ngaoundéré, Cameroon \\ ${ }^{2}$ Shanghai Institute of Technology, Shanghai, China \\ Email: *nmominou@yahoo.com
}

How to cite this paper: Nchare, M., Desire, E.O.B., Wang, L. and Sarki, B. (2018) Mineralogical and Physicochemical Characterization of Clay in the Sangaré-Paul Locality (North Cameroon), in Order to Assess the Potential Use in the Field of Ceramics. Open Journal of Inorganic Chemistry, 8, 71-80.

https://doi.org/10.4236/ojic.2018.83006

Received: June 22, 2018

Accepted: July 28, 2018

Published: July 31, 2018

Copyright (c) 2018 by authors and Scientific Research Publishing Inc. This work is licensed under the Creative Commons Attribution International License (CC BY 4.0).

http://creativecommons.org/licenses/by/4.0/

\section{(c) (i) Open Access}

\begin{abstract}
The clay in the locality of Sangaré-Paul referred to as SP, has been the subject of a mineralogical and physical characterization in order to assess the potential use in the field of ceramics. Firing experiments were carried out on experimental briquettes at temperatures of $900^{\circ} \mathrm{C}, 1000^{\circ} \mathrm{C}$ and $1100^{\circ} \mathrm{C}$ after which physical tests and mineralogical analyzes were made on the cooked products. The results obtained from the mineralogical analyses show that the clay in the locality of Sangaré-Paul contains kaolinite, illite, quartz and feldspar, and when cooked, the presence of a new crystal phase is detected. From the granulometrical and physical tests, the material has a particle size spread with a plasticity index greater than $20 \%$. Its activity is less than 0.75 . It is kaolinite sandy clay with a low plasticity. The hydrogen potential $(\mathrm{pH})$ measurement shows the weakly basic character of this clay. The technological parameters of experimental briquettes show that the percentage of water absorbed is less than $15 \%$. The linear withdrawal of all experimental briquettes presents values less than or equal to $10 \%$. The values of the mechanicals resistances of the briquettes increase globally with the temperature not exceeding $10 \mathrm{MPa}$ for the bending, but reaching $38 \mathrm{MPa}$ for the compression. All these parameters, except the linear withdrawal, present optima temperature at $1100^{\circ} \mathrm{C}$. The clay material of Sangaré-Paul is suitable for the manufacture of bricks and tiles at $1100^{\circ} \mathrm{C}$.
\end{abstract}

\section{Keywords}

Sangaré-Paul, Clay, Mineralogy, Ceramic 


\section{Introduction}

Clays have been used by man since the beginning of time. The natural abundance and immediate availability of clays explain their great uses over time. The peculiarity of this material is its capacity to have a plastic state with appropriate levels of water [1]. This material also has the power to be shaped, to shrink, to harden after drying and to consolidate after firing, which allows the formation of a vitreous phase more or less important [2]. This last discovery (consolidation by fire) was in the same way as the agriculture at the base of the first human civilization. Today, they are used as a minor constituent (paints, plastics, cosmetics, pharmaceuticals, etc.) as a majority raw material, for example for the production of widely used ceramic materials such as building materials and decorative objects. While the consumption of these products tends to become widespread, their production remains very unsustainable in some developing countries [3]. In Cameroon, for example, most industrial clay ceramics are imported. This situation can be explained by the virtual absence of a real industrial fabric and a poor estimate of the potential of local resources. In addition to this, the low level of popularization of quality ceramic products in our context may also stem from the poor mastery of production technologies that must first be based on the mineralogical and physicochemical characterization of the natural material.

The clay materials used for the production of ceramics are often complex natural mixtures of minerals whose granulometry and physicochemical properties are highly variable [4]. The user choice criteria are less related to the overall chemical and mineralogical composition of clay materials than to their behavior during the different stages of ceramic product manufacturing. This is extremely important because, due to lack of knowledge, it is often dried and cooked, giving poor quality ceramic products and generating many waste observed at the exit of the oven [5]. Whatever the type of ceramic to be obtained, the mineralogical composition of the clay material is important because it is dependent on the specific properties of the final product. It is therefore important to master these intrinsic parameters of the natural material before adapting the best techniques of elaboration. The mastery of the intrinsic parameters of the crystalline material passes through essential analyzes among which are X-ray diffraction analysis, which makes it possible to identify the crystalline phases that follow the evolution of the process in order to detect different physico-chemical phenomena which are occurring. Some work has already been carried out on the Cameroonian clay materials based on kaolinite, illite, smectite or talc [6]. This focused on the study of the physico-chemical characteristics, the catalytic properties and the thermal behavior of some sources of clay matter. The results of this work are intended to feed a sufficiently reliable database to support the start-up of industrial projects for local clay materials. The present work, focuses on the mineralogical and physical characterization of the clay material in the Sangaré-Paul locality (Garoua, North Cameroon).

The main objective of this work is to study the technological ability of this 
material for the manufacture of ceramic products for wide dissemination and sustainable local development. This study is a scientific contribution in the knowledge and characterization of industrial minerals which contributes to the promotion of local materials in Cameroon.

\section{Materials and Methods}

\subsection{Sampling}

Clay samples were collected from a well located at latitude $9.285126^{\circ}$ North and longitude $13.455767^{\circ}$ East. About $2.0 \mathrm{~kg}$ of each sample was collected and placed in small polythene bags. $1.0 \mathrm{~kg}$ of each sample was dried, pulverized and sieved before analysis. Documentary studies [7] suggested the clay nature of the grayish material.

The ENDECOTTS sieve series, a densimeter, a pycnometer, X-ray diffraction and infrared spectrometry were used to study the particle size as well as the physical and chemical properties of the material.

\subsection{Methods: Mineralogical Analyzes}

Mineralogical analyzes were performed using X-ray diffractometry (XRD) and infrared spectroscopy (IR). XRD was performed according to the protocol of the Laboratory of Geology and Sediment Environment (AGES) of the University of Liege in France. The data were recorded using a Brucker D8-Advance type diffractometer, and identification of the crystalline phases with DIFFRAC plus Release software 2000-EVA 6.

\section{Results and Discussion}

\subsection{Particle Size Analysis}

From the exploitation of the granulometric curve (Figure 1), we can observe that clay material of Sangaré-Paul has a very spread granulometry with a coefficient of uniformity greater than 200. It is sandy clay with a little silt and traces of gravel.

Granulometric analysis results show that the clay material is actually rich in clay and sand. The coefficient of uniformity being quite important, the grain size curve is much spread. The clay material is therefore good to be used in the manufacture of ceramic products. Indeed the grain size of a material for the manufacture of earth bricks must be spread [8]. It is also noted in the material that the percentage of elements whose diameter is less than $2 \mu \mathrm{m}$, clay fraction, is 46 $\%$.This value is greater than the $40 \%$ required producing fired bricks and/or tiles of very good quality [3]. The projection of the materials in the Winkler and Niesper diagram [9] (Figure 2), shows that it is propitious for the manufacture of tiles, and masonry bricks.

\subsection{Physical Properties}

The clay test results that allowed the determination of the Atterberg limits, the 


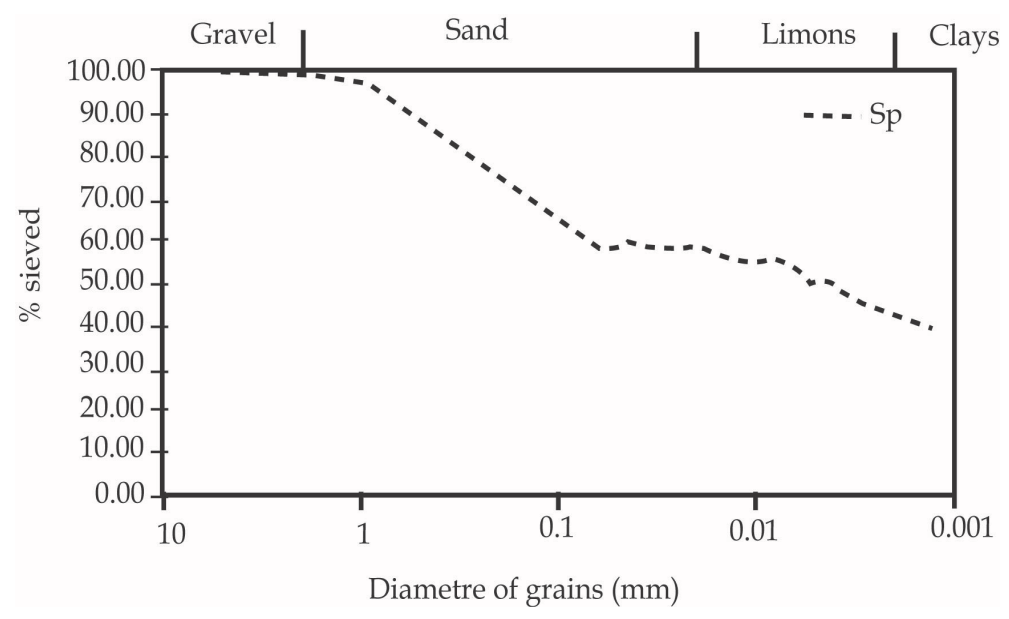

Figure 1. Granulometric curve of the studied material.

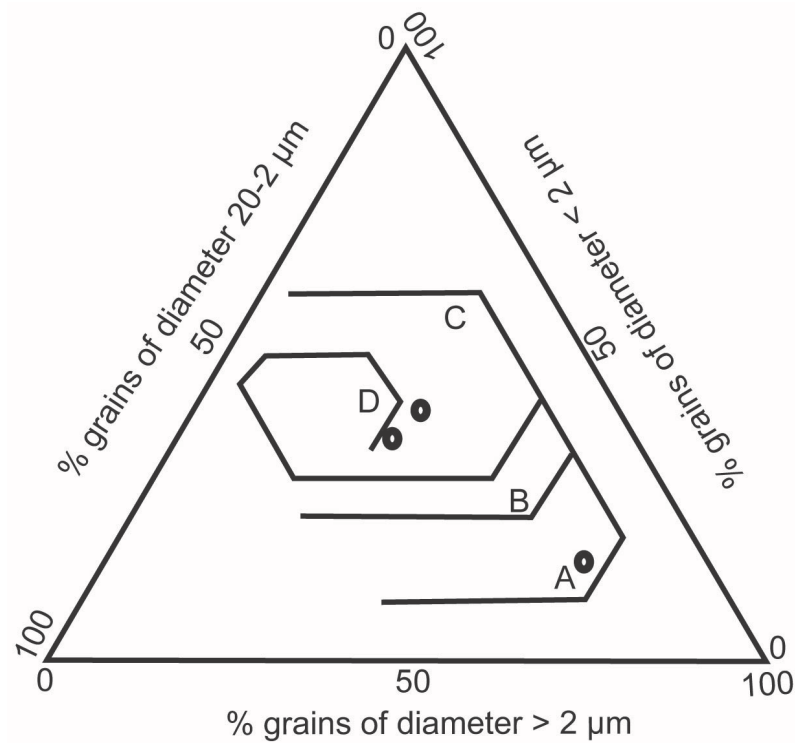

Figure 2. Position of the Sangaré-Paul clay material in the Winkler and Niesper diagram. (a) Dense bricks; (b) Perforated bricks vertically; (c) Tiles and masonry bricks; (d) Hollow products.

apparent density, the actual density, the volume of methylene blue and $\mathrm{pH}$ are given in Table 1.

From Table 1, we can see that Sangaré-Paul clay material can hold up to $30.63 \%$ of water without sinking under its own weight. It can deform plastically when it contains $9.21 \%$ of water. It is a little plastic clay, and it will not require a lot of water to form a paste of consistency and can support inert bodies (degreasing) while retaining an appreciable process ability and mechanical strength, dry enough to ensure fabrication [10]. Its plasticity index is $21.42 \%$. Compared to the reference clays used in industrial and traditional ceramics, the plasticity index of the Sangaré-Paul clay material is certainly high $(\geq 20 \%)$ but is still appreciable because the recommended plasticity index is between $9 \%$ and $20 \%$ 
Table 1. The physical properties of the Sangaré-Paul clay.

\begin{tabular}{cc}
\hline Liquidity limit $\omega_{\mathrm{L}}(\mathrm{c} / \mathrm{o})$ & 30.63 \\
Plasticity limit $\omega_{\mathrm{P}}(\mathrm{c} / \mathrm{o})$ & 9.21 \\
Plasticity Index Ip $(\mathrm{c} / \mathrm{o})$ & 21.42 \\
Apparent density $\left(\mathrm{g} / \mathrm{cm}^{3}\right)$ & 2.12 \\
Real density $\left(\mathrm{g} / \mathrm{cm}^{3}\right)$ & 2.42 \\
Volume of methylene blue $(\mathrm{ml})$ & 20 \\
$\mathrm{pH}$ & 8.1 \\
\hline
\end{tabular}

for the manufacture of clay bricks [10]. The apparent density is $2.12 \mathrm{~g} / \mathrm{cm}^{3}$; the real density is $2.45 \mathrm{~g} / \mathrm{cm}^{3}$ and the volume of methylene blue giving a positive test of $20 \mathrm{ml}$. According to the soil classification after the methylene blue test [11], it can be said that the Sangaré-Paul clay is sandy-clay. The real density and apparent density allow us to know the natural water content of the material and calculate the state parameters of the clay material. Sangaré-Paul clay has a $\mathrm{pH}$ level of 8.01. It is therefore considered as a weak basic clay. This would involve the presence in clay material in small amounts of calcite and basic soluble salts such as carbonates. Calcite has the ability to move freely in the solid phase of products during sintering [12]. Laboratory tests show that convincing results are obtained when $\mathrm{pH}$ of acid clays is taken between 6 and 8.5 and $\mathrm{pH}$ of neutral or slightly basic clays between 7.8 and 10.5 [13]. The clay material of Sangaré-Paul having a $\mathrm{pH}$ equal to 8.02 , will be adjusted by the addition of calcite so that it rises to between 9 and 10 , since it is a weak basic clay.

\subsection{Mineralogical Analyzes}

Examining the total powder diffractogram (Figure 3) obtained for the sample tested, shows the presence of minerals such as kaolinite (Kao), Illite (Ill), Quartz (Qz), Potassium feldspar (Fds).

Figure 4 shows the superposition of the diffractograms obtained on the powder of the raw material (SP1-N) and on the powders of the materials cooked at $950^{\circ} \mathrm{C}\left(\mathrm{SP} 1-950^{\circ} \mathrm{C}\right)$, at $1000^{\circ} \mathrm{C}\left(\mathrm{SP} 1-1000^{\circ} \mathrm{C}\right)$ and at $1100^{\circ} \mathrm{C}\left(\mathrm{SP} 1-1100^{\circ} \mathrm{C}\right)$.

Figure 4 shows the disappearance of certain phases with the evolution of the temperature. At the temperature of SP- $950^{\circ} \mathrm{C}$ on the diffractogram, the characteristic lines of kaolinite disappeared. Pabst, Gregorov and Ticha suggest that from $450^{\circ} \mathrm{C}$ up to $750^{\circ} \mathrm{C}$, the clay minerals decompose, losing their water content. This is the case of kaolinite which is converted into metakaolin $\left(2 \mathrm{SiO}_{2}\right.$, $\mathrm{Al}_{2} \mathrm{O}_{3}$ ) by dehydroxylation [14].

Then the metakaolin obtained is characterized by a lack of order at great distance in the arrangement of the constituent elements of its solid [15], which is not detectable by XRD. It is transformed into the spinel type phase $\left(\mathrm{Si}_{3} \mathrm{Al}_{4} \mathrm{O}_{12}\right)$ [16] with, in addition, $\beta\left(\mathrm{SiO}_{2}\right)$ quartz [17], which is a polymorph of silica at a temperature of $1000^{\circ} \mathrm{C}$ and at low pressure. 


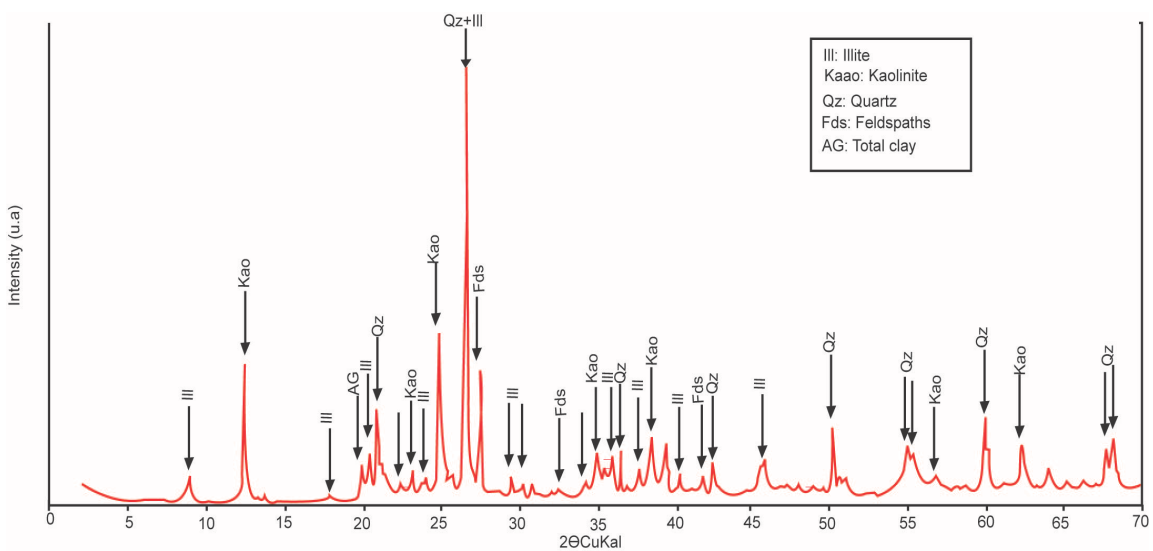

Figure 3. Diffractogram obtained in disoriented preparation on total powder.

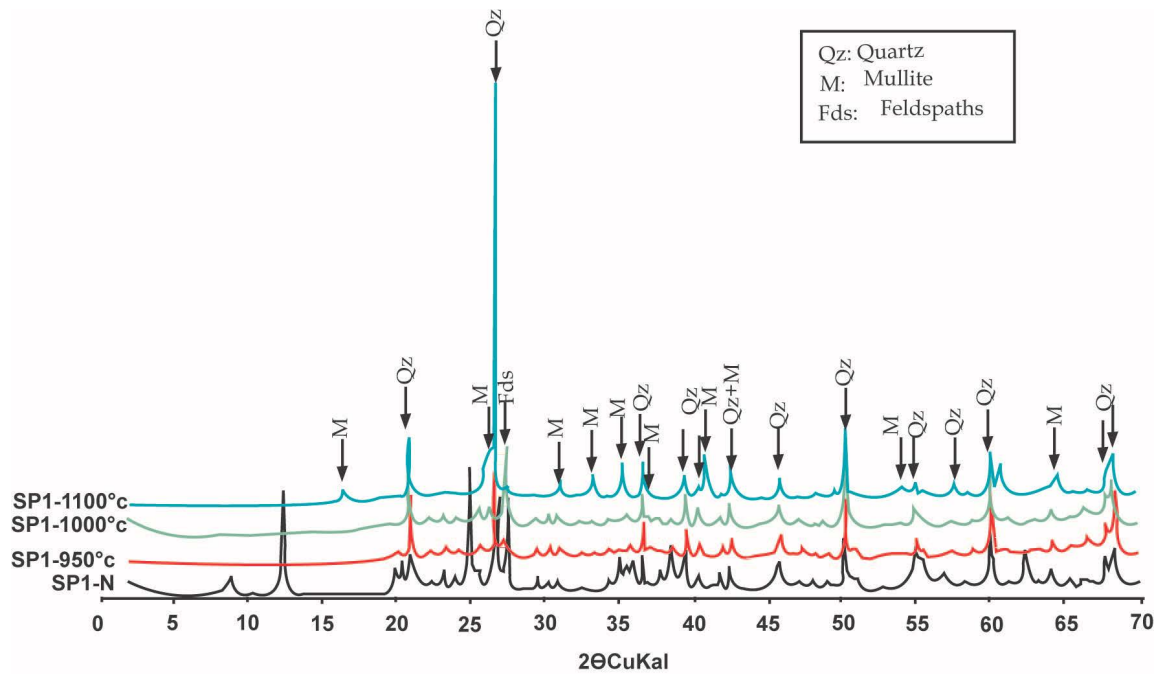

Figure 4. Superposition of the diffractograms obtained on the powders of the samples cooked at $950^{\circ} \mathrm{C}, 1000^{\circ} \mathrm{C}$, and $1100^{\circ} \mathrm{C}$.

The increase of the sintering temperature $\left(1100^{\circ} \mathrm{C}\right)$ leads to the disappearance of the spinel phase and the appearance of a high mullite content as shown by the SP1-1100 ${ }^{\circ} \mathrm{C}$ and SP1-1000 diffractograms with the multiplication of the main lines of mullite between $1000^{\circ} \mathrm{C}$ and $1100^{\circ} \mathrm{C}$. Mullite is an aluminum silicate that forms at high temperature and low pressure [2]. The mullite crystals $\left(3 \mathrm{Al}_{2} \mathrm{O}_{3}\right.$, $2 \mathrm{SiO}_{2}$ ) appear at $1000^{\circ} \mathrm{C}$ resulting from metakaolin and the spinel phase [2].

Figure 4 also shows the disappearance of illite phase; Huger suggests that illite, just below $1050^{\circ} \mathrm{C}$, becomes mullite [18]. Up to the sintering temperature of $1000^{\circ} \mathrm{C}$; residual peaks of illite which have dehydroxylated from $450^{\circ} \mathrm{C}$, are observed. At $1100^{\circ} \mathrm{C}\left(\mathrm{SP} 1-1100^{\circ} \mathrm{C}\right)$, these peaks disappear; the illite completely transforms into mullite during a mullitization parallel to that of metakaolin. [2]. Obtaining mullite from metakaolin and the spinel phase is due to primary mullitization [19].

Quartz and feldspars are present on all diffractograms obtained at different sintering temperatures tested. The melting point of quartz $\left(1700^{\circ} \mathrm{C}\right)$ and that of 
potassium feldspars $\left(1300^{\circ} \mathrm{C}\right)$ is much higher [17]. Quartz is nevertheless subjected to allotropic transformations which occur around $573^{\circ} \mathrm{C}$. The transformation of quartz from the so-called low-temperature form $\alpha$ to the so-called high-temperature form $\beta$, which is accompanied by a volume expansion. Around $600^{\circ} \mathrm{C}$, there is a reversible dimensional change characteristic of the quartz transition. Around $850^{\circ} \mathrm{C}$, it is transformed into $\beta$-quartz or tridymite according to the pressure gradient [17]. As long as it is not partially dissolved in the viscous flow, the quartz forms a percolating rigid skeleton which opposes the densification of the materials. The densification of ceramics is due to the formation of viscous flux from the dehydroxylation products of illite and kaolinite [2].

\subsection{Infrared Spectrometry}

The results of the infrared spectrometry analysis are shown in Figure 5. In the clay material of Sangaré-Paul, band characteristics of the presence of kaolinite (3689 $\mathrm{cm}^{-1}$ and $3649 \mathrm{~cm}^{-1}$ ) were found [20]. The band at $3619 \mathrm{~cm}^{-1}$ reflects the $\mathrm{O}-\mathrm{H}$ bond deformation and materializes the presence of kaolinite. The band at $1114 \mathrm{~cm}^{-1}$ and that at $1004 \mathrm{~cm}^{-1}$ correspond to the lengthening vibration of the Si-O bond of kaolinite [21] [22]. The bands observed around 914 and $916 \mathrm{~cm}^{-1}$ correspond to the deformation vibrations of the Al-O bond of the clay minerals [23]. The presence of Quartz is indicated by bands between 600 and $800 \mathrm{~cm}^{-1}$ [3].

\subsection{Quality Control Test on Ceramics Obtained}

The quality control tests carried out are designed to evaluate certain properties such as color, bulk density, mechanical flexural strength, compressive strength and linear shrinkage, loss of cooking mass and water absorption rate. Table 2 below summarizes all these properties.

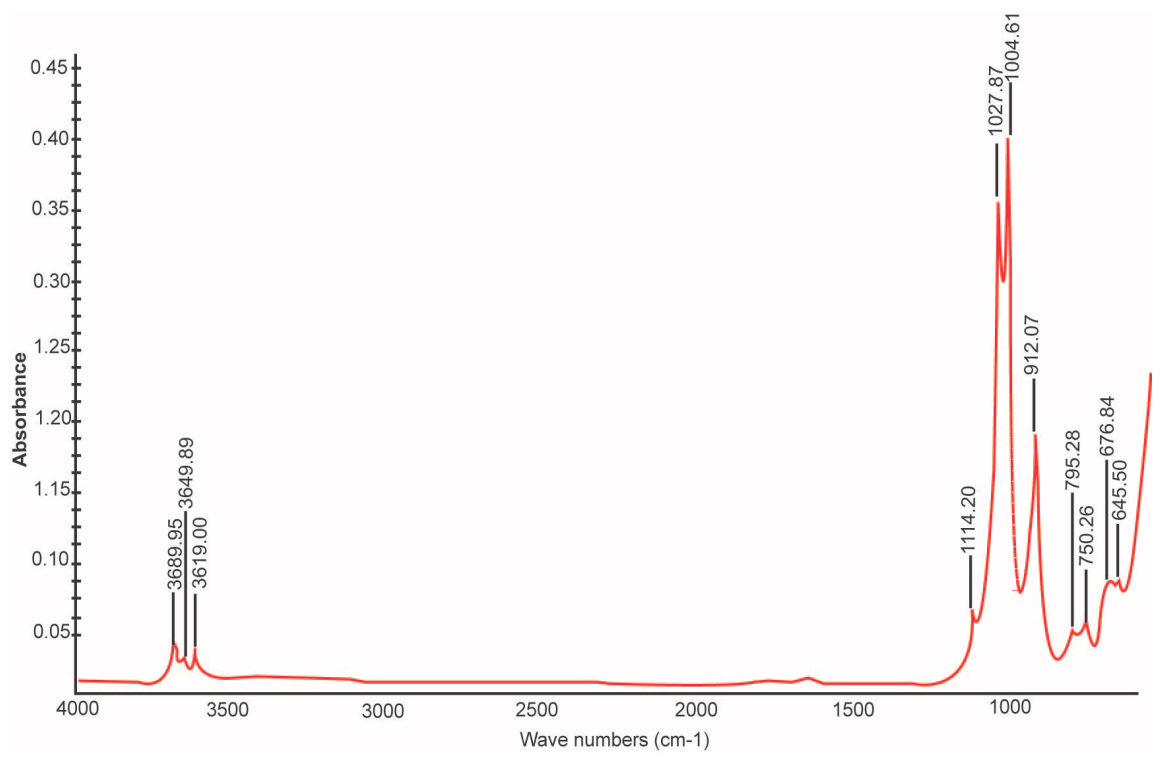

Figure 5. Infrared spectrum of analyzed material. 
Table 2. Physical and Mechanical Properties of ceramic products from Sangaré-Paul clay material.

\begin{tabular}{|c|c|c|c|}
\hline \multirow{2}{*}{ Technological parameters } & \multicolumn{3}{|c|}{ Temperature } \\
\hline & $950^{\circ} \mathrm{C}$ & $1000^{\circ} \mathrm{C}$ & $1100^{\circ} \mathrm{C}$ \\
\hline Colour (Munsell Charter) & $\begin{array}{c}\text { Clear yellowish } \\
7.5 \mathrm{Y} 9 / 2\end{array}$ & $\begin{array}{c}\text { Clear yellowish } \\
7.5 \mathrm{Y} 9 / 2\end{array}$ & $\begin{array}{c}\text { Dark yellowish } \\
7.5 \mathrm{Y} 9 / 4\end{array}$ \\
\hline Cohesion & Good & Good & Very good \\
\hline Sound & Light metallic & Metallic & Metallic \\
\hline Linear shrinkage $(\mathrm{c} / \mathrm{o})$ & 1.5 & 2.5 & 10 \\
\hline Mass loss (c/o) & 7.76 & 7.83 & 8.04 \\
\hline Mass density $\left(\mathrm{g} / \mathrm{cm}^{3}\right)$ & 1.87 & 1.92 & 2.06 \\
\hline Water absorption (c/o) & 14.06 & 12.24 & 6.38 \\
\hline Resistance to flexion (MPa) & 3.34 & 5.02 & 9.76 \\
\hline Resistance to compression ( $\mathrm{MPa})$ & 19.23 & 21.53 & 37.44 \\
\hline
\end{tabular}

\subsection{Determination of the Ideal Cooking Temperature of the Sangaré-Paul Clay Material}

To obtain bricks and even tiles of good quality as suggested by the diagram of Wrinkler and Niesper [9], from Sangaré-Paul clay material, it is essential to cook it at a temperature which gathers the greatest satisfaction from the point of view of technological parameters. These parameters include the loss of mass during cooking, the linear shrinkage during cooking, the rate of water absorption, the mechanical resistance to compression and bending.

From the graph presented in Figure 6, we see that for the three experimental temperatures, the optimum cooking temperature is $1100^{\circ} \mathrm{C}$ because it is a good compromise for all technological parameters mentioned. It makes it possible to avoid a water absorption rate greater than $10 \%$, to have maximum mechanical performances, a loss of mass at the conventional cooking and a linear shrinkage at the end of cooking.

\section{Conclusion}

The scientific knowledge acquired on the natural materials and on the manufactured specimens makes it possible to justify the use of the Sangaré-Paul clay materials in the coarse field of ceramic and construction materials. Indeed sintering found at $1100^{\circ} \mathrm{C}$ shows the sizzling and fusing nature of the natural material. In addition, the ideal particle size distribution for the manufacture of the fired bricks, the mechanical performance comparable to that of certain concretes and tiles, and the low mass loss and the rate of water absorption in accordance with the brick production criterion show the potential use of this clay material in coarse ceramics. The Sangaré-Paul clay is suitable for the manufacture of bricks and tiles at a temperature of $1100^{\circ} \mathrm{C}$. 


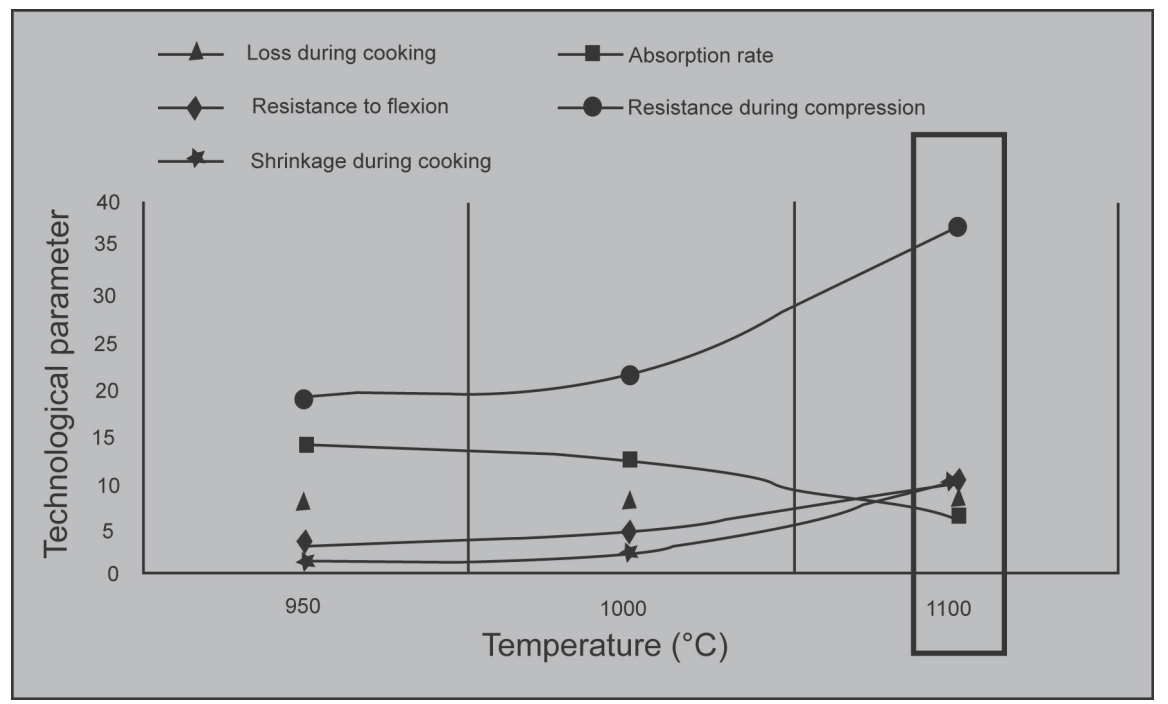

Figure 6. Determining the ideal cooking temperature.

\section{Conflicts of Interest}

The authors declare no conflicts of interest regarding the publication of this paper.

\section{References}

[1] Guggenheim, S. and Martin, R.T. (1995) Definition of Clay and Clay Minerals. Joint Report.

[2] Pialy, P. (2009) Etude de quelques matériaux argileux du site de Lembo (Cameroun): Minéralogie, comportement au frittage et analyse des propriétés d'élasticité. Thèse de Doctorat/PhD, Université de Limoges, Faculté des sciences et techniques, Limoges.

[3] Osomba, W. (2012) Caractérisation et valorisation des matériaux argileux de la Province de Kinshasa (RD Congo). Thèse de Doctorat, Université de Liège, Architecture, Géologie, Liège.

[4] El Yakoubi (2006) Potentialité d'utilisation d'argiles marocaines de JbelKharron et de Benhmed dans l'industrie céramique. Thèse de Doctorat, Université Mhammed 5-Agdal Géologie, Agdal, 42-64.

[5] Harat, M. (2007) Contribution à l'amélioration du procédé de fabrication des céramiques. Thèse de Magister, Génie des Procédés, Université KasdiMerbah Ouargla, Ouargla.

[6] Njopwouo, D. and Wandji, R. (1988) Minéralogie et comportement de quelques argiles camerounaises au renforcement du caoutchouc naturel par voie humide. Annales de la Faculté des Sciences, Université de Yaoundé, Yaoundé.

[7] Direction de la géologie et des mines (1979).

http://www.worldcat.org/title/carte-geologique-de-reconnaissance-du-cameroun-ga roua-ouest/oclc/81788746\&

[8] Bomeni, I.Y. (2013) Caractérisation minéralogique et physico-chimique des matériaux argileux de Babouantou: Valorisation dans la céramique traditionnelle. Mémoire de Magister, Université de Dschang, Dschang, 91.

[9] Kornman, M. (2009) Matériaux de terre cuite. Matières de base et fabrication. 
Éditions Techniques de l'Ingénieur, 2-20.

[10] Krause, E. (1977) Le séchage en céramique, principes et techniques. Septima, Paris.

[11] Classification des sols par la norme NF P 11300 et GTR (2017). http://www.louisthiriet.fr/UserFiles/files/THIRIET_Herimenil/Grave_0-125.pdf

[12] Traoré, K., Blanchard, P. and Jernot, J.P. (2007) Caractérisation physicochimique et mécanique de matériaux céramiques obtenus à partir d'une argile kaolinitique du Burkina Faso. Comptes Rendus Chimie, 10, 511-517. https://doi.org/10.1016/j.crci.2006.12.009

[13] Jouenne, C.A. (1984) Traité de céramique et matériaux. Septima, Paris.

[14] Pabst, W., Gregorová, E. and Tichá, G. (2006) Elasticity of Porous Ceramics-A Critical Study of Modulus-Porosity Relations. Journal of the European Ceramic Society, 26, 1085-1097. https://doi.org/10.1016/j.jeurceramsoc.2005.01.041

[15] Sanz, J., Madoui, A., Serrodosa, J.M., Moya, J.S. and Aza, S. (1988) Aluminium-27 and Silicium-29 Magic Angle Spining Nuclear Magnetic Resonnance Study of Kaolinite-Mulite Transformation. Journal of America Ceramic Society, 71, C418-C421. https://doi.org/10.1111/j.1151-2916.1988.tb07513.x

[16] Brindley, N.M. (1988) Nouveau concept sur les réactions de passage. Kaolinite-Mullite, 25-26.

[17] Pondichery (2013) Diagramme (température-pression), Domaine de stabilité des minéraux.

[18] Tessier-doyen, N., Glandus, J.C. and Huger, M. (2006) Untypical Young's Modulus Evolution of Model Refractories at High Temperature. Journal of the European Ceramic Society, 26, 289-295. https://doi.org/10.1016/j.jeurceramsoc.2004.10.028

[19] Sobgwi, T.E. (2005) Contribution à l'étude physico-chimique et minéralogique des matériaux du gisement argileux de Mayouom (Ouest-Cameroun): Cas des matériaux du puits numéro 1. Mémoire de magister, Université de Yaoundé I, Yaoundé, 64.

[20] Saikia, J.B. and Parthasarathy, G. (2010) Fourier Transform Infrared Spectroscopic Characterization of Kaolinite from Assam and Meghalaya, Northeastern India. Journal of Modern Physics, 1, 206-210. https://doi.org/10.4236/jmp.2010.14031

[21] Aarfane, A., Salhi, A., El Krati, M., Tahiri, S., Monkade, M., Lhadi, E.K. and Bensitel, M.J. (2014) Matériaux et Environnements. Sci. 5-6.

[22] Maglione, G. and Carn, M. (1975) Spectres infrarouges des minéraux salins et des silicates néoformés dans le bassin Tchadien. Cah. ORSTOM, Géol., 7, 3-9.

[23] Bishop, J., Madejovaâ, J., Komadel, P. and Froè Schl, H. (2001) The Influence of Structural $\mathrm{Fe}, \mathrm{Al}$ and $\mathrm{Mg}$ on the Infrared $\mathrm{OH}$ Bands in Spectra of Dioctahedral Smectites. Clay Minerals, 37, 607-616. 